\title{
Research on Innovative Practical Teaching Mode of Clothing and Fashion Design Specialty
}

\author{
Xiaofang Ma \\ Academy of finearts \\ Yanbian University \\ Yanji, China
}

\begin{abstract}
Taking market as core, employment-oriented, capability-based and practice-based innovative practical teaching mode is an effective way to improve teaching quality and teaching achievement of costume and fashion design specialty in higher education. From the perspective of the market supply and demand, it cultivates clothing and fashion design professionals for the enterprises. And these are effective measures to strengthen the resources for business professionals. With the diversified development of China's modern garment industry, colleges and universities should make step-by-step and planned transformation of college personnel according to the specific requirements of enterprises and markets. And then, it would enhance the market match between graduates of clothing and fashion design specialty in higher education and garment enterprise. This article analyzes the current situation and development trend of clothing industry, and points out the importance of innovative practice teaching and training mode around the specific requirements of the clothing market supply and demand. The students can get close contact with the market and enterprises. Then, colleges and universities can cultivate innovative, high-quality, competitive and outstanding professionals of clothing and fashion design to meet the social needs.
\end{abstract}

\section{Keywords - innovation; practice; teaching mode}

\section{INTRODUCTION}

In nearly 40 years, China's higher education of clothing and fashion design specialty has made great development. And it has established a relatively complete teaching and training mode of clothing and fashion design. So far, hundreds of thousands of clothing and fashion design professionals have been cultivated. In recent years, as the apparel industry continues to grow, competition in the apparel market is becoming more and more intense. As a result, there is an increasing demand for innovative and practical clothing design professionals in the domestic apparel market. The talent training mode of higher education of clothing and fashion design specialty should serve the garment enterprises. The demand for clothing and fashion design professionals in apparel enterprises should always be the goal of clothing and fashion design professionals. It not only meets the current needs of employers, but also promotes the development of enterprises. The clothing and fashion design specialty combines the characteristics of art and practice technology, and pay attention to the technical practicality of work. There is an urgent need to explore innovative and practical teaching models that adapt to China's higher clothing and fashion design specialty. Also, colleges and universities should strengthen the organic combination of art and technology practice, and promote students' practical ability and innovative thinking. The innovative practical teaching mode is important teaching content in the field of clothing and fashion design specialty in higher education. The key point is to cultivate students practical ability and innovative thinking. Colleges and universities should pay attention to the application of the knowledge of art theory and practical operation. The clothing and fashion design specialty is highly innovative and practical. The innovative practice teaching model plays an irreplaceable role in cultivating students' innovative spirit, consciousness and ability. At present, the clothing and fashion design specialty in colleges and universities lags behind theoretical teaching to a large extent in practical teaching. And the students' practical abilities are obviously insufficient. There is a certain gap between the professionals of clothing and fashion design specialty and the talents in garment industry. The graduates' practical ability, innovative ability and comprehensive ability are weak. And these students can't adapt to the rapid development of the appare industry. How to cultivate clothing and fashion design professionals who adapt to the development of the times and the market demand has always been the common task of clothing and fashion design specialty of the colleges and apparel enterprises.

Innovative practical teaching mode is of great significance to the teaching of clothing and fashion design specialty in higher education. According to the industrial background and social needs, the colleges and universities could determine the training objectives. According to the training objectives, they could set the practical teaching content. Taking the practical teaching as a combination of theory and practice, knowledge and ability, they could cultivate the innovation spirit and ability of the students from the classroom practice teaching, extracurricular practice teaching, academic activities, internships and graduation design, social practice and other practical aspects. Then, it could form a set of practical teaching content system that adapts to the clothing and fashion design specialty. And it also promotes the sound and sustainable development of clothing and fashion design specialty of higher education. 


\section{TO IMPROVE PRACTICAL TEACHING CONTENT OF THE Course, AND to Promote STUdents' Practical ABILITY}

With the analysis of the professional abilities of the clothing and fashion design professionals in higher education at this stage, there is a widespread problem of weak practical ability. Students' professional theoretical knowledge is strong, and their practical skills are generally weak. The reasons for this are closely linked with the current teaching mode of clothing and fashion design specialty. In the course of clothing and fashion design specialty of domestic higher education, the basic courses and theoretical courses account for a large proportion of class hours. The courses of practice and production account for a relatively small proportion of class hours. The clothing and fashion design specialty to a large extent has affected by art education. For a long time, the colleges and universities focus on the theory, pay little attention to the practice, emphasis on art, pay little attention to technology, and emphasis on teaching and scientific research issues. The market awareness of the students is weak. The teaching and industry are seriously out of line. Therefore, there is a certain gap between clothing and fashion design professionals and the actual needs of professionals of apparel companies.

The colleges and universities should optimize the curriculum, rationally formulate theory class hours and practice hours. The students should have theoretical study and the practice. The colleges and universities should focus on the effective combination of art, technology practice and the market. Such as the style design and production in "Draping", the sewing and production in "Clothing Sewing Technology", the clothing accessories design and production in "Clothing Accessories", as well as the courses of "Apparel Marketing" and "Clothing Production Management" and other courses require students to combine theoretical knowledge with practical operation. And then, the theory can be applied in practice. It would promote students' digestion of knowledge and deepen their understanding of theory. Students can master the clothing production technology to solve the problems of clothing and fashion design, clothing technology, clothing production management and other problems. The colleges and universities should focus on training students in garment production technology management, marketing and business practices and other comprehensive ability. Then, students would be ready for the job. In order to achieve the close docking with the garment industry, practice teaching is particularly important. Practical teaching is an important complement to theoretical teaching. Through practice, students are trained to apply theoretical knowledge in a comprehensive manner. In the professional courses, the teachers should take the teaching mode of practice - theory, and re-practice. Then, the teaching mode would integrate the theory with the practice. Practice teaching is based on a broader platform, which can be in classrooms, studios, garment exhibitions, garment enterprises, simulation production internships and other forms. The students pay attention to realizing the society, learning about the enterprise and understanding the fashion trends in the apparel market. Students' works would be close to life and the market. Then, it would meet the needs of the apparel industry.

\section{TO INNOVATE EXTRA-CURRICULAR PRACTICE}

\section{A. To Participate in Clothing Events, and to Carry Out Practical Activities}

The colleges and universities should actively encourage students to participate in various domestic and international fashion and apparel design competitions. The teachers provide students with competition information, also should make guidance of students' competition works. Through various costumes and fashion design contest, it can exercise students' creative thinking, promote innovative awareness, improve students' professional ability, develop students' innovative ability, and test the teachers' teaching quality and teaching achievement. The colleges and universities could combine the requirements of the costume and fashion design contest with the courses. And they can establish the reward system. It would inject new fashion connotation for the single and fixed professional courses. At the same time, through the enterprise products and competitions, they can exchange the practice content. According to the targeted market research and brand research, it could enhance students' understanding of the brand awareness and the market. The students would have better understanding of the connotation of clothing and apparel design. And design work would meet the demands of the market, and follow the fashion development. The works created by students in practice activities are rewarded, honored, praised by the society and recognized by apparel enterprises. They provide students a broader space for development and lay a good foundation for future employment.

\section{B. To Strengthen the School-enterprise Cooperation, and to Cultivate High-quality Personnel}

At present, both the knowledge structure and the economic structure have undergone tremendous changes. The links among the higher apparel education, the apparel market and the apparel enterprises should be strengthened. The premise of employment should be given in the teaching of colleges and universities. A mechanism of mutual exchange should be established between colleges and enterprises. School-enterprise cooperation is the inevitable trend of clothing and fashion design specialty of higher education to adapt to today's economic development. And it is the teaching mode of cooperation between schools and enterprises to train qualified personnel. According to the requirements of the teaching content, students are allowed to participate in all aspects of design and production in the enterprise to carry out practical operation. Schools and enterprises combine production with learning, and professional theories and production practices are combined. Colleges and universities should combine the theoretical teaching of knowledge-based teaching in the classroom with the production and scientific research of direct acquisition of practical experience. It could establish the market concept of students, enhance the strength of running a school and the quality of personnel training, narrow the gap between school 
personnel training and social talent demand, solve the problem of school education being out of step with the needs of social enterprises, and improve students' adaptability to society. Through the cooperation between schools and enterprises, we have established a solid practical teaching model of win-win cooperation between schools and enterprises. And it has enhanced the initiative of enterprises and education. Then, it has reached a new situation of cooperation and education, cooperation and employment, and cooperation and development. The colleges and universities should combine the professional education with the community and enterprises. It would promote the professional development and the cultivation of comprehensive ability of students. Then, it would form a relationship of organic combination, resource sharing and interactive development between the professional and the enterprises.

\section{To Create School-enterprise Teaching Team}

"If the students just have the learning, they would have no friends. And they would know nothing." According to participating in domestic and foreign advanced education, seminars on apparel and fashion design, training for enterprises, research projects and technical service projects, teachers can improve their abilities in teaching, scientific research and practical operation. They also can improve the ability to solve problems of actual production. They also can update knowledge with the times. We should integrate the university resources with clothing business resources, and establish the teacher teams consist of university teachers, experts, business designers and other people. The universities should employ technicians and designers from the field of enterprise production practice to serve as parttime teachers to make the teaching, to participate in teaching and practice and other teaching activities, to make comments on students' works and propose amendments. The universities regularly organize lectures for students. The students can realize the latest developments and research results of the major and related majors. Students can feel the corporate culture. And it could effectively achieve the docking between the school cultures with the corporate culture. Then, it would form the teaching structure of "school-enterprise practice, the combination of full-time and part-time teachers". With school-enterprise exchange, teachers can understand the development of enterprises, learn from each other, and better implement the teaching reform.

\section{To Establish the Studio Teaching Mode}

Studio teaching is an innovative teaching mode, which is the extension of classroom teaching. It is teaching space for guidance and practice. It is an open teaching mode oriented towards practice of teaching, teaching and practice. Practical courses of the studio teaching enable students to better apply professional theoretical knowledge to practice. In practical links, it can be extended to the network, the market and businesses. The colleges and universities could carry out simulation or actual design — production — marketing training. And the colleges and universities could increase practice hours. Students can understand some abstract theoretical concepts through practical aspects. Students master the process of transforming theoretical knowledge into practice. And it expands the scope of teaching activities and shortens the distance among schools, markets and enterprises. The studio is a link between classroom and market, and a bridge of cooperation between schools and enterprises. And the market evaluation is included in the teaching quality evaluation system. And then, the colleges and universities could cultivate different talents to meet the market demands. With the practice of studio teaching mode, we could develop teamwork and communication and coordination skills of the students. After graduation, the students would integrate faster into the enterprise. They could adapt to the workplace as soon as possible. It would shorten the adaption time and improve the employment rate of students. The establishment of studio teaching mode puts forward higher requirements on teachers' professional abilities. Teachers can enrich themselves in the teaching process. And then, they would improve their comprehensive abilities. Students can master the theoretical knowledge through the teaching mode of studio system. They can also have more skilled practical ability and innovation ability. With the combination of theory and practice, it would achieve the integration of theory and practice teaching.

\section{E. To Encourage Students to Actively Participate in the Practice of Scientific Research}

On the one hand, students are encouraged to declare and undertake innovative projects at university level, provincial level and national level with the guidance of teachers. On the other hand, students should be encouraged to participate in the scientific research projects undertaken by teachers. They could accomplish scientific research tasks with their teachers. By participating in teachers' scientific research projects, students have mastered the process of applying for and reporting on scientific research projects. They have also enhanced students' practical abilities and the level of scientific research. More importantly, they have effectively guided and stimulated students' innovative awareness and innovative thinking. The horizons, innovation and practical ability and overall quality of the students have been well improved.

\section{TO STRENGTHEN STUDENTS' INTERNSHIPS}

As important practical teaching content in teaching process, internship is an important way to combine theoretical knowledge with practical skills. It is a bridge to cultivate students' understanding of society, garment market and garment enterprises. And they could contact with actual production. Relying on the society, the colleges and universities should establish the relationship between school and enterprise, expand teaching resources, break the status quo of the separation among the classroom teaching, society and business, and establish a solid base for the internship. The colleges and universities should encourage students to have short-term internship practice in the internships, businesses or factories in holidays. It could create conditions for the practice. Different internships and positions can train students in different aspects of the ability. Through internships, students can gain exposure to the corporate 
culture earlier, be familiar with the work environment, develop workplace skills, broaden their horizons and clarify the direction of their efforts. Through internships, students can apply their theoretical knowledge and professional knowledge to practical work and further define the direction of employment for their own development, and complete the smooth transition from students to professionals. In practice, the students could understand the production process, accept the influence of corporate culture, and comprehensively cultivate the ability of students to engage in practical work. And then, it would achieve the purpose of personnel training to meet the needs of the community.

\section{THE COMBINATION OF GRADUATION PROJECT TOPICS AND INDUSTRIAL DEVELOPMENT}

Graduation project is the summative teaching practice in undergraduate teaching. Through graduation project, we can comprehensively examine the combined application of theoretical knowledge and practical skills of the students. The selected topic of graduation project should be adapted to the current development needs of the garment industry. It requires students to conduct in-depth market research during the graduation project, fully understand the actual needs of the current apparel market and the latest fashion trends to carry out graduation project work. Apparel technology backbones directly engaged in the graduation project guidance and graduation project evaluation. And the colleges and universities would establish a market-oriented education concept; make marketized examination of the graduation project to see whether it meets the actual needs of the market, whether it is adopted by the related industries. It would be an important basis for the evaluation of achievement of graduation design. The colleges and universities should encourage students to participate in the process of filming, designing and making graduation works. And it can improve students' comprehensive practical ability. Through the dynamic catwalks activities of graduation works, the students should complete the organization planning, production of advertising posters, catwalks music selection, model hair, makeup, performance arrangements, appearance order, catching the process of shooting with the guidance of teachers. The completion of these practical operations can improve the overall ability and overall quality of students. They could complete the smooth transition from the design to employment. Then, it would meet the market demand for composite design talent.

\section{CONCLUSION}

The innovative practical teaching mode of clothing and fashion design specialty enables students to achieve close contacts with the market and business. And then, it would cultivate innovative, high-quality, competitive and outstanding apparel and fashion design professionals to meet the community needs.

\section{REFERENCES}

[1] Yin Wei, Chen Dongsheng. The formulation of training program of apparel and fashion design professional talents. Textile and Garment Education, 2014, 3

[2] Ren Zhexue. Practice teaching model of clothing and fashion design Education, 2015, 13

[3] Li Guangsong. Innovative training model of clothing and fashion design. Shandong Textile Economy, 2014, 3

[4] Zhang Ning. Applied training of garment and fashion design in applied universities. Art Education Research, 2014, 15

[5] Liu Fengxia. Teaching research and exploration on applied talents in clothing and fashion design specialty of colleges and universities Journal of Changchun Institute of Technology (Social Science Edition), 2015, 1 